\title{
The phylogeny of marine and freshwater species of the genus Chloromyxum Mingazzini, 1890 (Myxosporea: Bivalvulida) based on small subunit ribosomal RNA gene sequences
}

\author{
Ivan Fiala and Iva Dyková
}

Institute of Parasitology, Academy of Sciences of the Czech Republic, Branišovská 31, 37005 České Budějovice, Czech Republic and Faculty of Biological Sciences, University of South Bohemia, Branišovská 31, 37005 České Budějovice, Czech Republic

Key words: Myxosporea, Chloromyxum, SSU rDNA, phylogeny, taxonomy

\begin{abstract}
The small subunit ribosomal RNA gene (SSU rDNA) of two freshwater and one marine species of the genus Chloromyxum Mingazzini, 1890 were sequenced. The SSU rDNA trees obtained show the phylogenetic position of the marine species Chloromyxum leydigi Mingazzini, 1890 to be at the base of the freshwater clade, being well supported by a high bootstrap value. Chloromyxum cyprini Fujita, 1927 is closely related to Chloromyxum truttae Léger, 1906 and they represent a sister branch to raabeia sp., Myxidium sp. and Myxidium truttae Léger, 1930. Chloromyxum legeri Tourraine, 1931 is in a position ancestral to Myxidium lieberkuehni Bütschli, 1882 and Sphaerospora oncorhynchi Kent, Whitaker et Margolis, 1993. Three newly sequenced species of the genus Chloromyxum represent three separate lineages within the myxosporean tree and do not support the monophyly of this genus.
\end{abstract}

The genus Chloromyxum Mingazzini, 1890 includes over one hundred species from freshwater and marine fish hosts. They are coelozoic parasites living in the gall bladder and urinary tract. Species of the genus Chloromyxum have spherical or slightly elongate spores with or without ridges on the surface. The pattern of the ridges on the valve of the spore is very important for the description of individual species (Lom and Dyková 1993). Four polar capsules are at the apex of the spore. Small plasmodia are monosporic while those of medium size are polysporic.

The potential different phylogenetic origin of marine and freshwater Chloromyxum spp. might concord with differences of the morphology of the spore, and plasmodium and host preferences. Species from the marine environment have broadly oval spores with an attenuated apex and a posterior bunch of filamentous appendages. They are only found in the gall bladder of elasmobranch hosts (Kuznetsova 1977, Kovaleva 1988). Freshwater Chloromyxum spp. are mostly spherical or subspherical with surface ridges on shell valves. They infect the gall bladder or urinary tract of teleosts and exceptionally amphibians (Lom and Dyková 1993).

Data on the SSU rDNA of the genus Chloromyxum are very poor. Only one sequence of a named species, C. truttae Léger, 1906, is currently available in GenBank and a preliminary phylogenetic analysis was presented by Holzer et al. (2003). Previous phylogenetic analyses presented myxosporeans as divided into two main clades including largely freshwater and marine species, recpectively (Kent et al. 2001). Because species of Chloromyxum are described from both freshwater and marine environment, the monophyly of the genus may be put in doubt. Concordant with Kent et al. (2001), the species of the genus Myxidium sequenced so far fit accurately the division to the marine and freshwater clade. For the marine, histozoic and enteric species with Myxidium-like shape of spore a new genus Enteromyxum was established (Palenzuela et al. 2002). Regardless, few exceptions are found in the marine/ freshwater branching pattern, e.g. Ceratomyxa shasta Noble, 1950, secondarily adapted to freshwater, is branching within the marine clade (Kent et al. 2001).

The fact that generic classification of myxosporea, based mainly on morphology of spores, does not agree with molecular data is well known. Most genera present in myxosporean SSU rDNA tree are poly/paraphyletic (Kent et al. 2001). Only the genus Kudoa seems to be clearly monophyletic, regardless of the unusual spore morphology of $K$. permulticapsulata (Whipps et al. 2003).

Using SSU rDNA analysis, the present work is intended to resolve the phylogenetic position of some marine and freshwater species of the genus Chloromyxum and find out the mutual relationship of the studied species.

\section{MATERIALS AND METHODS}

Collections of myxosporean spores. Fresh spores of Chloromyxum spp. were collected during the spring of 2002. Chloromyxum cyprini Fujita, 1927 and C. legeri Tourraine, 1931

This paper was presented at the 6th International Symposium on Fish Parasites in Bloemfontein, South Africa, 22-26 September 2003. 
were found in the gall bladder of Hypophthalmichthys molitrix Valenciennes and Cyprinus carpio L., respectively, from the Třeboň pond area in the Czech Republic. Chloromyxum leydigi Mingazzini, 1890 was isolated from the gall bladder of Torpedo marmorata Risso from the Mediterranean Sea, off the Croatian coast. Infected gall bladders were checked carefully to ensure that there was no contamination with spores of other species. The spores were cleaned from bile with distilled water and used for morphological and molecular characterisation.

DNA isolation, cloning and sequencing. DNA was extracted from fresh spores using the DNeasy ${ }^{\mathrm{TM}}$ Tissue Kit (Quiagen, Germany) according to the manufacturer's protocol. The SSU rRNA gene was PCR amplified with a set of universal eukaryotic primers (ERIB1: ACCTGGTTGATCCTGC CAG and ERIB10: CTTCCGCAGGTTCACCTACGG) (Barta et al. 1997). PCR was carried out in a $25 \mu 1$ reaction volume using $10 \mathrm{pmol}$ of each primer, $250 \mu \mathrm{M}$ of each dNTP, and 2.5 $\mu 110 \times$ PCR Buffer (Top-Bio, Czech Republic) and 1 unit of Taq-Purple polymerase (Top-Bio, Czech Republic). The reactions were run on a Tpersonal cycler (Biometra). Amplification consisted of 30 cycles of $95^{\circ} \mathrm{C}$ for $1 \mathrm{~min}, 48^{\circ} \mathrm{C}$ for $1 \mathrm{~min}$ and $72^{\circ} \mathrm{C}$ for $2 \mathrm{~min}$, then a $10 \mathrm{~min}$ incubation at $72^{\circ} \mathrm{C}$. Amplification products were gel isolated and cloned into $\mathrm{pCR}^{\circledR} 2,1$ TOPO Cloning vector using the TOPO-TA Cloning Kit (Invitrogen). Clones were sequenced from both strands on automatic sequencer $\mathrm{CEQ}^{\mathrm{TM}} 2000$ (Beckman Coulter) using CEQ DTCS Dye Kit (Beckman Coulter) according to the manufacturer's protocol.

Phylogenetic analysis. The SSU rDNA sequences of Chloromyxum spp. were aligned using the Clustal_X program (Thompson et al. 1997) with 23 selected sequences of myxosporeans taken from GenBank. The dataset was aligned with gap opening / gap extension penalty $=8 / 2$. Tetracapsuloides bryosalmonae and Buddenbrockia plumatellae were set as outgroup.

The alignment was analysed using the program package PAUP*, Version 4.0b8 (Swofford 2001). Phylogenetic analyses were done using the maximum parsimony (MP) and maximum likelihood (ML) methods. The MP analysis was done using heuristic search with random addition of taxa (10 replications) and the ACCTRAN-option. Gaps were treated as missing data. Each matrix was analysed under the 1:1, 1:2 and 1:4 transition/transversion (Ts/Tv) ratios. For the ML analysis, the likelihood ratio test (LRT) implemented in Modeltest v. 3.06 (Posada and Crandall 1998) was used to determine the best model of evolution. Based on the LRT, the ML was performed with the $\operatorname{TrN}+\mathrm{I}+\Gamma$ model of evolution. Clade support was assessed with bootstrapping (1000 and 500 replicates for MP and ML, respectively).

\section{RESULTS}

The morphology and size of myxosporean spores (Fig. 1), as well as characteristics of vegetative stages, confirm the identity of the species studied as Chloromyxum leydigi, C. cyprini and C. legeri, respectively.

The length of the SSU rDNA sequences of the marine $C$. leydigi is much shorter (1868 bp, GenBank Acc. No. AY604199) than that of the freshwater species $C$. legeri (2042 bp, GenBank Acc. No. AY604197) and
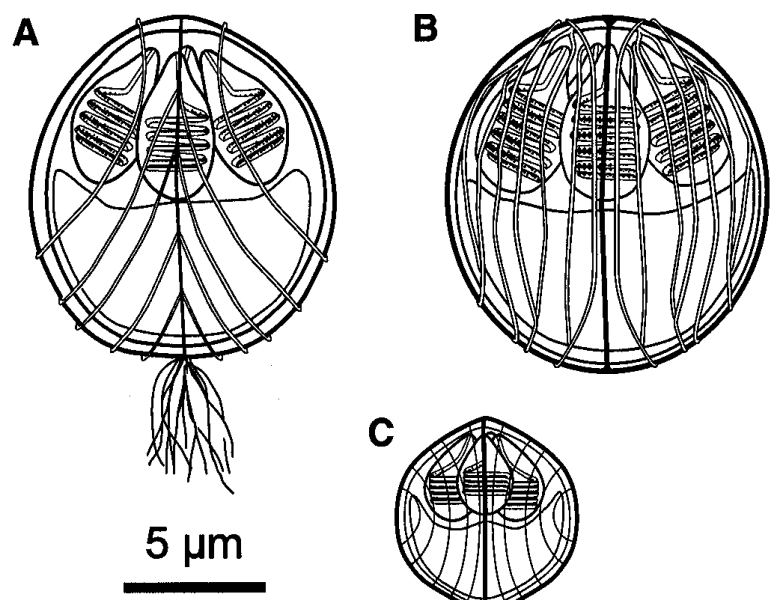

Fig. 1. Drawings of the mature spores of Chloromyxum spp. A-C. leydigi; $\mathbf{B}-$ C. cyprini; $\mathbf{C}-$ C. legeri.

C. cyprini (2126 bp, GenBank Acc. No. AY604198). The resulting alignment consisted of $1811 \mathrm{nt}$ positions (666 ambiguously aligned positions were excluded). The number of parsimony informative sites was 845 . The alignment is accessible at the web site http:// www.paru.cas.cz/myxoalign01. In the alignment, all freshwater myxosporea have many nucleotide insertions between positions 1770-2040 (deduced from the ancestral state of Tetracapsuloides bryosalmonae and Buddenbrockia plumatellae) corresponding to the variable region V7 of the secondary structure of SSU rDNA.

The MP analyses under three different $\mathrm{Ts} / \mathrm{TV}$ ratios always resulted in one shortest tree $(\mathrm{Ts} / \mathrm{Tv}=1: 1,3605$ steps; Ts $/ \mathrm{Tv}=1: 2,5086$ steps; Ts/Tv $=1: 4,8028$ steps). Fig. 2 shows the ML tree computed under $\operatorname{TrN}+\mathrm{I}+\Gamma$ model selected by LRT with the score of the best tree $-\ln =17888.2823$. In both (MP and ML) analyses, myxosporea divided into two previously known subgroups. The newly sequenced Chloromyxum spp. did not form a monophyletic group. The marine $C$. leydigi represented a branch ancestral to all freshwater myxosporeans with a rather high bootstrap support. Chloromyxum cyprini clustered together with $C$. truttae (taken from GenBank) and formed a sister clade to a group including raabeia sp., Myxidium sp. and $M$. truttae. Chloromyxum legeri clustered with Myxidium lieberkuehni and Sphaerospora oncorhynchi with high bootstrap support. The topologies described above (Fig. 2) were stable in all trees. The marine clade was poorly resolved in comparison with the clade represented by the largely freshwater species.

\section{DISCUSSION}

The sequences of SSU rDNA of the Chloromyxum spp. under study differ in length. There is a conspicuous variance between the marine $C$. leydigi and both fresh- 


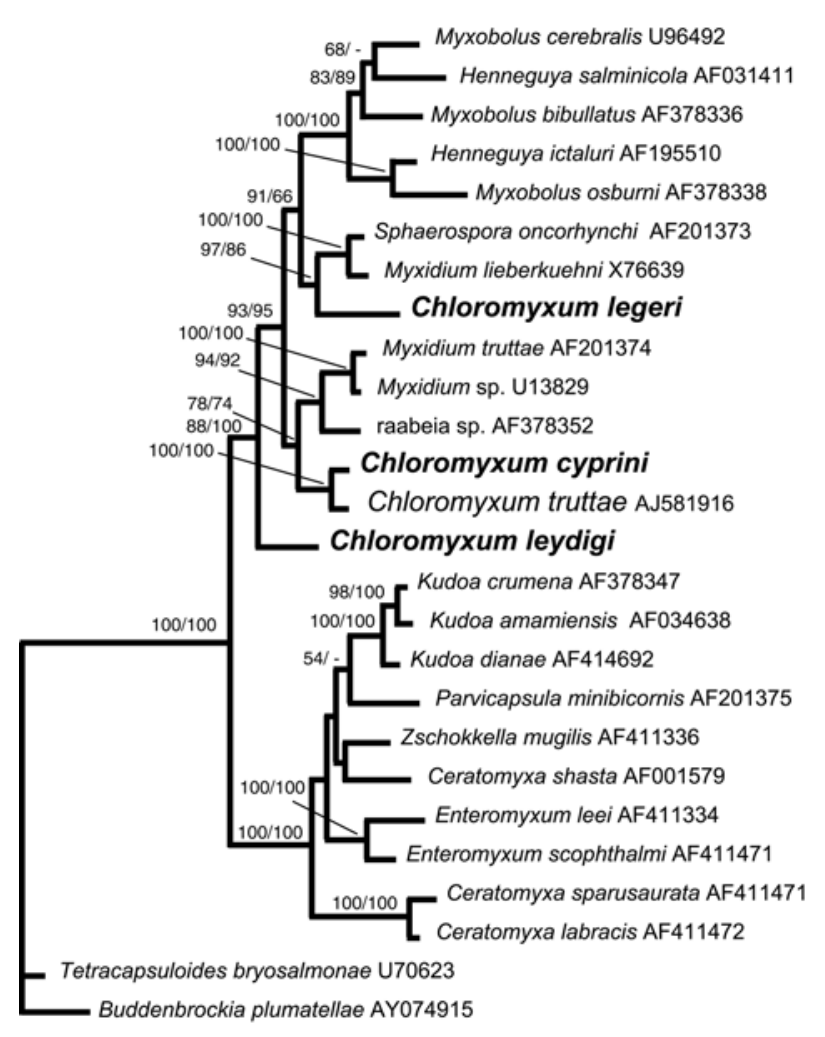

$\underline{0.1}$

Fig. 2. The maximum likelihood tree of SSU rDNA sequences of myxosporeans. Tetracapsuloides bryosalmonae and Buddenbrockia plumatellae were set as an outgroup. Bootstrap values (ML and MP Ts/Tv = 1:2) are indicated for the nodes gaining more than $50 \%$ support. The scale is given under the tree (substitution/site).

water species, C. cyprini and C. legeri. The sequence of C. truttae from GenBank is very similar to C. cyprini but cannot be compared in length with the analysed sequences because of different, more internal PCR primers used for amplification. Compared with the model of secondary structure of SSU rDNA (Wuyts et al. 2000), the discrepancy in length of sequences is caused by the presence of numerous insertions in the V7 region. This feature is unique in freshwater myxosporea and is not known in marine myxosporea (see alignment at http:// www.paru.cas.cz/myxoalign01) and in a huge range of eukaryotes.

The phylogenetic position of Chloromyxum spp. is not consistent with the morphological similarity of the spores. The Chloromyxum species included in the study do not form a monophyletic group. They are spread into the three separate lineages within the freshwater clade of myxosporeans. Only the clade with $C$. cyprini and $C$. truttae seems monophyletic even though the features of the spore, type of plasmodia and hosts may not suggest a direct relationship. They form a sister group to Myxidium truttae, Myxidium sp. (U13829) and the actinosporean raabeia sp. (AF378352). Similarly, C. legeri is in a close relation with Myxidium lieberkuehni and Sphaerospora oncorhynchi. Despite of the "marine" characteristic of the V7 region of SSU rDNA, C. leydigi clusters with freshwater myxosporea and represents the most basal lineage of the freshwater clade.

The phylogenetic positions of other myxosporeans correspond more or less to previous studies (Kent et al. 2001, Palenzuela et al. 2002). The different branching pattern of the marine group can be explained by low bootstrap support of internal nodes.

In classification of myxosporeans, the genus Chloromyxum is placed within the suborder Variisporina including mostly coelozoic species (Lom and Dyková 1992). Chloromyxum spp. under study are coelozoic and branching as the basal lineages within the mostly freshwater clade concordantly with Shulman's (1966) consideration that coelozoic species are more primitive evolutionarily than histozoic species.

Chloromyxum leydigi presents an exception to the hypothesis of freshwater/marine division of myxosporeans known to the present date. The hosts of marine Chloromyxum spp. are elasmobranchs and this might explain a different evolution history. Four sequenced species are a small fraction of more than hundred described species of the genus Chloromyxum; thus future research in this field may modify the phylogenetic tree.

Acknowledgements. The authors are grateful to the Ministry of Education, Youth and Sports of the Czech Republic for financial support of this research (Project MSM 12300003) and Grant Agency of the Czech Republic (project 524/03/ H133).

\section{REFERENCES}

BARTA J.R., MARTIN D.S., LIBERATOR P.A., DASHKEVICZ M., ANDERSON J.W., FEIGHNER S.D., ELBRECHT A., PERKINS-BARROW A., JENKINS M.C., DANFORTH H.D., RUFF M.D., PROFOUSJUCHELKA H. 1997: Phylogenetic relationships among eight Eimeria species infecting domestic fowl inferred using complete small subunit ribosomal DNA sequences. J. Parasitol. 83: 262-271.

HOLZER A.S., SOMMERVILLE C., WOOTTEN R. 2003: Communities of myxosporeans and actinosporeans in a Scottish highland stream and their molecular relationships based on 18S rDNA sequences. 11th International Conference of the European Association of Fish Pathologists, 21st-26th September 2003, Malta. Book of abstracts, P070.

KENT M.L., ANDREE K.B., BARTHOLOMEW J.L., ElMATBOULI M., DESSER S.S., DEVLIN R.H., FEIST S.W., HEDRICK R.P., HOFFMANN R.W., KHATTRA J., HALLET S.L., LESTER R.J.G., LONGSHAW M., PALENZUELA O., SIDDALL M.E., XIAO C. 2001: Recent advances in our knowledge of the Myxozoa. J. Eukaryot. Microbiol. 48: 395-413. 
KOVALEVA A.A. 1988: Myxosporidia of the genus Chloromyxum (Cnidospora, Myxosporea) of cartilaginous fish from the Atlantic Coast of Africa. Parazitologiya 22: 384 388. (In Russian.)

KUZNETSOVA I.G. 1977: Myxosporidians of Chondrostei from the Patagonian shelf. Parazitologiya 11: 74-77. (In Russian.)

LOM J., DYKOVÁ I. 1992: Protozoan Parasites of Fishes. Developments in Aquaculture and Fisheries Science 26. Elsevier Science Publishers, Amsterdam, 315 pp.

LOM J., DYKOVÁ I. 1993: Scanning electron microscopic revision of common species of the genus Chloromyxum (Myxozoa: Myxosporea) infecting European freshwater fishes. Folia Parasitol. 40: 161-174.

PALENZUELA O., REDONDO M.J., ALVAREZ-PELLITERO P. 2002: Description of Enteromyxum scophthalmi gen. nov., sp. nov. (Myxozoa), an intestinal parasite of turbot (Scophthalmus maximus L.) using morphological and ribosomal RNA sequence data. Parasitology 124: 369-379.

POSADA D., CRANDALL K.A. 1998: Modeltest: testing the model of DNA substitution. Bioinformatics 14: 817-818.
SHULMAN S.S. 1966: [Myxosporidia of the Fauna of the USSR]. Nauka, Moscow, 504 pp. (In Russian.)

SWOFFORD D.L. 2001: PAUP*: Phylogenetic Analysis Using Parsimony, Version 4.0b8. Sinauer Associates, Sunderland, MA.

THOMPSON J.D., GIBSON T.J., PLEWNIAK F., JEANMOUGIN F., HIGGINS D.G. 1997: The CLUSTAL_X windows interface: flexible strategies for multiple sequence alignment aided by quality analysis tools. Nucleic Acids Res. 25: 4876-4882.

WHIPPS C.M., ADLARD R.D., BRYANT M.S., KENT M.L. 2003: Two unusual myxozoans, Kudoa quadricornis n. sp. (Multivalvulida) from the muscle of goldspotted trevally (Carangoides fulvoguttatus) and Kudoa permulticapsulata n. sp. (Multivalvulida) from the muscle of Spanish mackerel (Scomberomorus commerson) from the Great Barrier Reef, Australia. J. Parasitol. 89: 168-173.

WUYTS J., De RIJK P., Van de PEER Y., PISON G., ROUSSEEUW P., De WACHTER R. 2000: Comparative analysis of more than 3000 sequences reveals the existence of two pseudoknots in area V4 of eukaryotic small subunit ribosomal RNA. Nucleic Acids Res. 28: 4698-4708.

Accepted 12 May 2004 